\title{
LAS NAVES DE LEPANTO. LAS GLORIAS DE JERÓNIMO CORTE REAL
}

Data recepción: 2012/01/12

Data aceptación: 2012/07/05

Contacto autora: tesinerva@yahoo.es
Rosa Margarita Cacheda Barreiro Universidade de Santiago de Compostela

\section{RESUMEN}

La obra Felicissima victoria concedida del cielo al señor don Juan de Austria en el golfo de Lepanto de la poderosa armada otomana nos propone una aproximación a la glorificación literaria de la batalla de Lepanto. Su autor, el portugués Jerónimo Corte Real, escribe este poema épico en el último tercio del siglo XVI, basándose en los relatos mitológicos, en los autores clásicos y en la literatura del Renacimiento. Sus constantes recursos a lo sobrenatural impregnan el texto y, por consiguiente, sus ilustraciones, de matices que juegan con una combinación en el plano de lo imaginario y de lo real, de lo pagano y de lo cristiano.

Palabras clave: batalla, mitología, iconografía, imagen, Venus, Marte, literatura clásica.

\section{ABSTRACT}

The epic poem Felicissima victoria concedida del cielo al señor don Juan de Austria en el golfo de Lepanto de la poderosa armada otomana is a literary glorification of the battle of Lepanto. Written by the Portuguese writer Jeronimo Corte Real in the last third of the 16th century, it is based on mythological tales, the classical authors and the literature of the Renaissance. The writer's continual references to the supernatural infuse the text and its illustrations with nuances that play on a combination of the imaginary and the real, and the pagan and the Christian.

Keywords: battle, mythology, iconography, image, Venus, Mars, classical literature.

Lepanto representó la victoria de la cultura cristiana contra la amenaza de oriente, por entonces casi secular; y a España, exuberante como ahora de catolicidad y de fe en sus destinos, le cupo el papel más brillante de la victoria

Con estas palabras se resumía el papel de la Armada Española en las conferencias que, sobre Lepanto, se llevaron a cabo en el Museo Naval de Madrid en su IV centenario'. La victoria conseguida por la armada de la Santa Liga, en el golfo de Lepanto, el 7 de octubre de 1571, tuvo una importante repercusión en la historia y en el arte occidental de su época y de los siglos venideros. Junto a la célebre pintura de Vasari, numerosas obras de arte fueron testigo de un acontecimiento tan trascendental en la historia de España y de
Europa, en la segunda mitad del siglo XVI2; la serie de la batalla que Luca Cambiaso realiza para el monasterio de san Lorenzo de El Escorial ${ }^{3}$, el retrato de Sebastiano Vernier -capitán general de la flota veneciana- con la escena del combate al fondo o las pinturas que con diferentes tipos de navíos conmemoraron la victoria en la iglesia de Santa Maria in Ara Coeli en Roma, son algunos de los numerosos ejemplos.

La historia del libro no es ajena a esta notable repercusión. Desde el siglo XVI salieron a la luz, en los diversos talleres europeos, obras relativas al acontecimiento bélico. En este sentido, tenemos que recordar el poema titulado The Lepanto que escribió Jacobo VI de Escocia en 1585, la Canción en alabança de la divina magestad por la vitoria del Señor Don Juan de Fernando de Herrera ${ }^{4}$ impreso en 1591 o el poema épico La 
Austriada publicado unos años antes, en 1584 También del Renacimiento son las obras de Ambrosio de Morales o la Relacion de la gverra de Cipre y svcesso de la batalla Naual de Lepanto, de Fernando de Herrera, publicada en Sevilla en el año $1572^{5}$.

Un siglo después la repercusión de tan célebre acontecimiento no se dejó esperar; el propio Miguel de Cervantes -que se había quedado manco en la batalla- lo citaba en la segunda parte del Quijote ensalzando el triunfo de la armada cristiana hasta tal punto que prefiere "haberse hallado en aquella facción prodigiosa, à verse sano de sus heridas sin haber estado en ella"6. De la misma centuria tenemos que citar el acto tercero de la Liga Santa de Lope de Vega ${ }^{7}$ y El águila del agua de Luis Vélez de Guevara en el año $1642^{8}$.

A lo largo del siglo XVIII se siguen publicando relatos sobre la victoria lepantina y así se manifiesta en los impresos de José Fernández de la Puente $^{9}$ o la Historia del combate naval de Lepanto de Cayetano Rosell, impreso en el año 1853.

Con todo, uno de los poemas épicos más representativos de esta época es el titulado Felicissima victoria concedida del cielo al señor don Juan de Austria, en el golfo de Lepanto de la poderosa armada otomana, en el año de nuestra salvación de 1572. Escrito por Jerónimo Corte Real, poeta, músico y pintor portugués, se imprime en Lisboa en 1578. La Felicissima victoria, objeto de este estudio, se constituye como una de las obras más emblemáticas por ser uno de los pocos que desarrolla este combate, a juicio de Lara Vilà, de "manera exclusiva y con una notable extensión"10.

Jerónimo Corte Real fue nieto de Gaspar Corte Real que estuvo al servicio de D. Manuel I en África y de Brites de Mendoza, dama de la reina D. Catarina; se casó en 1561 con D. Luisa da Silva que era hija del poeta Jorge de Vasconcelos ${ }^{11}$; su vínculo a los grandes linajes de la época y, en especial, al mundo de las letras y de las armas, será un elemento a tener en cuenta a la hora de analizar e interpretar el significado final de sus obras. Junto a la Felicissima victoria, Jerónimo Corte Real escribió otros dos poemas épicos, de temática histórica; el primero impreso en Lisboa por Antonio Gonzálvez en el año 1574, titulado Sucesso do segundo cerco de Diu: estando dõn Joham Mazcarenhas por Capitam da fortaleza. Año de 1546 y uno segundo, póstumo, sobre el Naufragio e lastimoso sucesso da pediçam de Manoel de Sousa de Sepulveda, \& Dona Lianor de Sá sua molher \& filhos, vindo da India para este Reyno da nao chamada o galião grande $S$. loão que se perdeo no cabo de boa Esperança, na terra do Natal, Simão Lopes, 1594.

La impresión de Felicissima victoria se acompaña de 15 grabados -que ilustran los 15 cantos de los que se compone el libro- diseñados por Jerónimo Corte Real, pues, como lo confirma en el prólogo de su obra, solía ser el ilustrador de sus propios libros:

Mucha vezes dudó S.C.R.M. aceptar esta empressa... assi colgado de varios discursos pasé muchos dias, hasta que, vencido de mi antiguo desseo... aunque fuere con la dureza y sequedad que en estos mis mal pulidos versos y baxo estilo claro se muestra... la lengua y frasis castellana escogí, aunque murmurado y argüido de algunos de mi patria... por estos y por otros mil inconvenientes he pasado y a todo fácilmente a resistido el deseo de presentar a V. M. este libro, debuxado de mi mano, para que... la invención de la pintura (a que Vuestra Magestad es inclinado) haga facil aquel peso y molestia de una lectura falta de invención y de aquel ornamento y polido estilo que en los grandes $y$ agudos ingenios solo se hallan ${ }^{12}$.

\section{MITOLOGÍA Y HEROICIDAD. LA IDENTI- DAD NACIONAL EN LAS IMÁGENES DE FELI- CISSIMA VICTORIA}

La tradición clásica simboliza algo más que la recuperación de los motivos de la antigüedad y su habitual reutilización en los siglos XV y XVl; su presencia ha sido constante en diferentes períodos de la historia y las manifestaciones artísticas han dejado innumerables huellas que corroboran este hecho.

En este sentido, tenemos que partir de varias premisas; por un lado el significado del término clasicismo como una imitación de los modelos derivados de la Antigüedad clásica, por otro, el 
ideal clásico como un estilo de forma y contenido y, en último término, la importancia constante de la cultura antigua en disciplinas como la historia del arte, la literatura y, por extensión, la historia del libro. Desde este punto de vista, los impresos de época moderna supusieron un instrumento de vital importancia para la circulación de ese ideal clásico: un instrumento capaz de organizar un contenido y unas ideas y de transmitirlas y plasmarlas en las diferentes ilustraciones; en definitiva, un ideal clásico que respondía al famoso aforismo horaciano ut pictura poesis.

No es ajeno a esta repercusión los relatos de sucesos y los poemas épicos del siglo XVI. Tenemos que tener en cuenta que la aparición de este tipo de textos tiene "el impacto certero de autentificar el relato" que se está narrando pero también presenta "un segundo efecto, menos evidente, de proyectarlo hacia una dimensión mítica desde la que es posible reinterpretar" todo el texto ${ }^{13}$. La mitología está presente en estos documentos como un nexo de unión de los protagonistas con los héroes de la Antigüedad clásica. Autores como Ovidio ${ }^{14}$, Plutarco, Séneca, Virgilio habían sido fuente de información sobre temas mitológicos antiguos ya desde época medieval y, especialmente, durante el Renacimiento. A lo largo del siglo XVI la aparición de obras como Le imagini de i Dei de gli antichi de Vicenzo Cartari, los Diálogos de medallas, inscripciones y otras antigüedades de Antonio Agustín o los Discursos de la Religión de Guillaume de Choul son clave para entender la reinterpretación de conceptos clásicos en un contexto humanista.

Jerónimo Corte Real se empapó de toda esta literatura, inspirándose en los relatos legendarios y mitológicos que pudiesen dar forma al texto y a las imágenes de Felicissima Victoria. Sus constantes recursos a lo sobrenatural impregna el poema de matices que juegan con una combinación en el plano de lo imaginario y de lo real, de lo pagano y de lo cristiano.

En el canto I (Fig. 1), Jerónimo Corte Real nos presenta la figura alegórica de la Guerra que abandona el infierno para persuadir a Selim a atacar a la cristiandad; en el centro de la composición se representa el sueño del sultán de conquistar Chipre. La imagen se acompaña del texto explicativo:

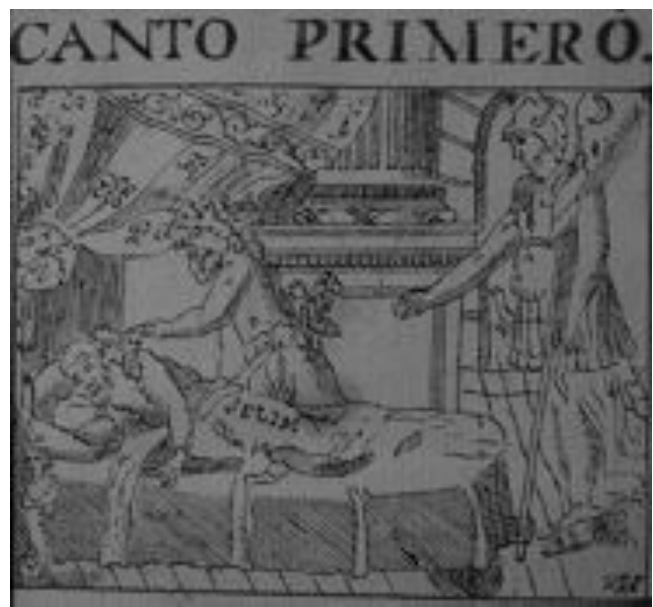

Fig. 1. Canto I, Sueño de Selim. Jerónimo Corte Real, Felicissima Victoria, Lisboa, 1572

En este primer canto sale la guerra del infierno, en sueños persuade Selim, emperador de los Turcos que conquiste à Cipro. Manda Selim llamar sus baxas de cuyo consejo, sale tomarse aquella isla, para lo qual se percibe una poderosa y fuerte armada ${ }^{15}$.

La referencia al Hades es constante en los relatos mitológicos clásicos; la Miníada de Pausanias desarrolla parte de sus fragmentos en el inframundo, lo mismo que el mito de Orfeo con el rescate de Eurídice o el viaje de Ulises al palacio de Hades, "mansión de la terrible Perséfone" en la Odisea de Homero' ${ }^{16}$.

Por otro lado, el sueño es otra llamada al mundo clásico. Aristóteles en su obra Sobre el sueño y la vigilia explica que "durante el sueño los sentidos están impedidos debido a ciertas emanaciones y vaporizaciones" (De Somno et Vigil. 454b). En la Edad Media existe una clara distinción entre visión y sueño. Santo Tomás en sus profecías escribía que "a los profetas se imprimían u ordenaban formas imaginarias, bien fuera mientras dormían, lo cual se significa por el sueño, o durante la vigilia, lo cual se expresa en visión"(Summa II-II, c.173). Santo Tomás profundizará sobre la materia del sueño y la visión en diversas cuestiones de la Suma, pero es importante tener en cuenta que 
los sueños pueden ser elegidos por Dios para comunicar sus proyectos a los hombres, y por los demonios para revelar los sucesos futuros a quienes hacen pactos con ellos... si alguien, para pronosticar cosas futuras, se basa en aquellos sueños que proceden de revelación divina o de causas naturales, intrínsecas o extrínsecas, sin salirse del campo de acción de tales causas, no será ilícita su adivinación $n^{17}$.

Desde el punto de vista iconográfico, el sueño se representa, en la escultura helenística, como una figura reclinada, con uno de los brazos sirviendo de apoyo a la cabeza ${ }^{18}$. De este modo se representa al sultán otomano, que duerme plácidamente mientras otra figura intenta despertarle apoyando unas hojas de planta sobre su cabeza; se trata de la alegoría del Sueño caracterizado como un joven que cubre su cabeza con hojas de adormideras pues ya Virgilio y Ovidio calificaban esta planta como "soporífera". Cumont, explicando el simbolismo funerario romano, incide en este aspecto: "La adormidera, de la que los antiguos conocían sus efectos soporíferos y sabían extraer el opio, se escogió para servir de emblema del sueño. Esta planta pertenece, en efecto, a Hipno y caracteriza sus imágenes"19. En los sarcófagos romanos es frecuente encontrarnos a Hipno rodeado de figuras dormidas ${ }^{20}$, siguiendo los postulados iconográficos que le describen como un personaje que duerme, rodeado de sus hijos, en una gruta "donde crecen adormideras y otras plantas narcóticas"21.

A los pies de Selim se sitúa Marte, el dios de la guerra, que llama al sultán a combate. La iconografía de Marte responde a los modelos clásicos que le representan con la cabeza protegida por el casco y armado con una lanza, como dios eficiente, cuya principal misión consistía en velar por la guerra y ayudar al vencedor; no en vano su culto estaba muy difundido, entre los romanos, que consideraban a Marte como el padre de Rómulo y el protector del Imperio 22 .

De este modo, Marte será uno de los protagonistas de las imágenes de Felicissima Victoria acompañando a sus protagonistas hasta el final de la historia. En el canto XIV (Fig. 2), el dios de la guerra, representado en la parte superior, lanza un dardo y mata "al Supremo General de los

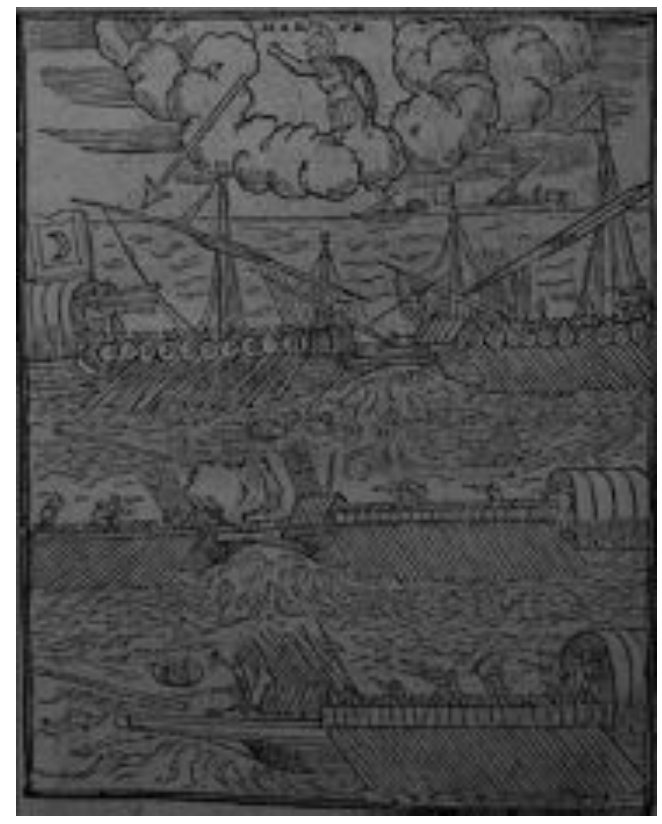

Fig. 2. Canto XIV, Marte dando muerte al Supremo General de los turcos. Jerónimo Corte Real, Felicissima Victoria, Lisboa, 1572

Turcos"23. La presencia del turco en el Mediterráneo fue considerada una amenaza constante, en especial, a partir de la rebelión morisca de 1568 y el riesgo de la conexión musulmana a uno y otro lado del Mediterráneo ${ }^{24}$. Durante la primera mitad del siglo XVI, el Imperio cristiano de Carlos $\checkmark$ y el Imperio Otomano de Solimán el Magnífico concentraron fuerzas irreparablemente antagónicas. El Mediterráneo se convirtió, a ojos de la cristiandad, en un espacio cruel y peligroso para navegantes y viajeros ${ }^{25}$. La Inquisición se encargó de propagar una idea basada en la conjura musulmana entre moriscos, berberiscos y turcos, que los cristianos tenían que contraatacar con una férrea defensa pues

la armada del turco no puede venir en danyo destos reynos en confianza de los moriscos de Aragón y Valencia no teniendo puerto donde recoger su armada y que tampoco puede hacer que los moriscos de Valencia se ayan de levantar no teniendo cierto el socorro y venida del turco pues por un morisco hay veinte cristianos viejos ${ }^{26}$. 


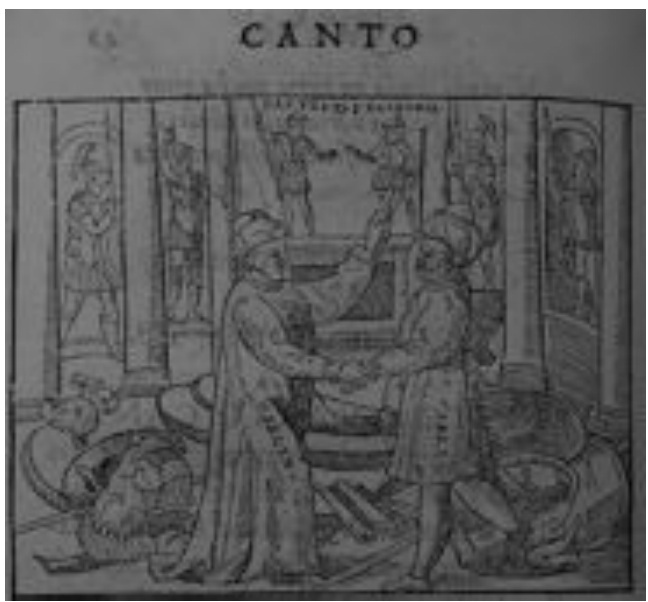

Fig. 3. Canto IV, Sueño de Ali Bajá. Jerónimo Corte Real, Felicissima Victoria, Lisboa, 1572

La presencia de Alí Bajá, el gran almirante de la flota imperial otomana, personificaba este peligro. Jerónimo Corte Real lo presenta en el canto IV (Fig.3) utilizando, una vez más, el recurso clásico del sueño. En esta ocasión el templo de Marte sirve de referencia a la escena que nos muestra a Selim en un primer plano estrechando su mano al general turco. La imagen recoge el momento en que Alí Bajá tiene un sueño en que se le representa el templo de Marte y le anuncian la batalla de Lepanto. De este modo lo expresa el autor portugués:

En este quarto canto, Alî Baxâ mirando el cielo, vee quasi todas las figuras de las estrellas, que por los orbes celestes se mueven. Vencido del sueño, le aparece el Emperador Selim.. Ilevalo al templo de Marte, donde le muestra algunos capitanes Españoles... y mostrandole al señor don Juan d'Austria le declara el desventurado sucesso que ha de venir a su armada, vencida por este glorioso principe ${ }^{27}$.

La referencia al mundo clásico es evidente. Por una parte, la presencia del templo de Marte incide en el aspecto que ya nos presentaba en el primer canto con la personificación de la Guerra. En las medallas de Augusto el dios guerrero se representa en el interior de su templo como símbolo de la victoria y el triunfo. Guillaume de

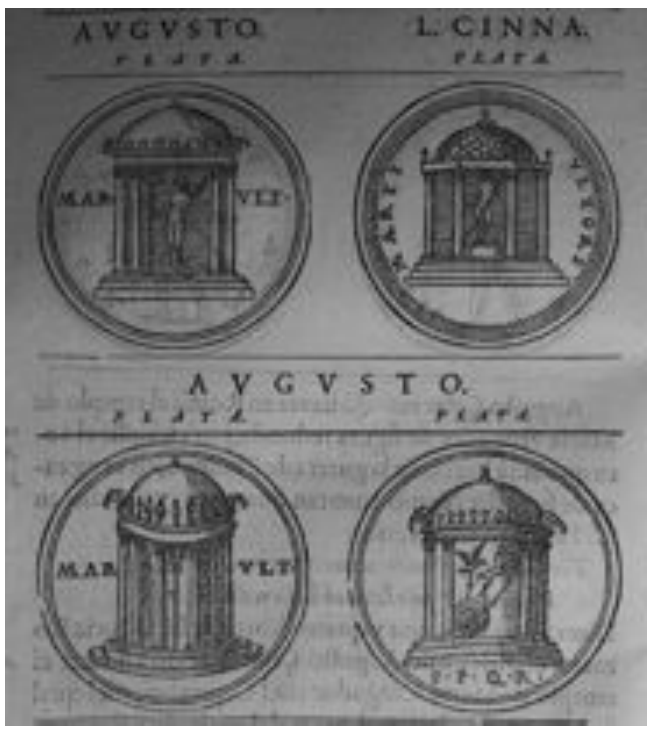

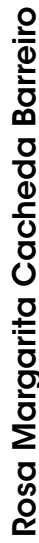

Fig. 4. Templo de Marte. Guillaume de Choul, Discursos de la religión, 1579

Choul (Fig. 4), en los Discursos de la religion, incide en este aspecto:

Augusto Cesar mando hazer en Roma el templo de Marte, vengador, de figura redonda, por cumplir el voto que avia hecho en la guerra de Philippo, en vengança de su padre, como cuentan Suetonio y Ovidio en sus Fastos... Dion à los cinquenta y quatro libros de su historia Romana, escribe que, Augusto Çesar mando edificar el templo de Marte Vengador en el Capitolio en el qual fueron puestas las vanderas y el aguila que llevavan en la guerra los Romanos ${ }^{28}$.

Por otro lado, la moda persa se impone también en los personajes retratados; la imagen de Alí Bajá no es novedosa en las relaciones de sucesos de esta época. Pedro de Oviedo describe al general de la armada turca -que había sido rey de Argel- de esta manera:

vestido de seda con marlota turquesa y verde, el turbante con la media luna y la cimitarra en la mano diestra. La caracterización del rostro sugería fiereza y denuedo grande, y la seguridad de la mano izquierda, confiança en la victoria. 
Este modelo corresponde a la imagen que circulaba en España de los bajás y sultanes: "altivos, soberbios y codiciosos" ${ }^{\prime 2}$. En el conjunto de relaciones se insistía en aspectos relacionados con la crueldad, la violencia y la agresividad del turco:

Y su reputado arrojo es más temeridad que valentía, insaciable borrachera de sangre de quien acude a la batalla sin tener nada que perder, instigado por la superstición lo que explica su celo guerrero ${ }^{30}$,

frente al valor, la justicia y la magnanimidad de los generales cristianos; así lo explica Ambrosio de Morales en uno de sus opúsculos dedicados a la batalla de Lepanto en el que se hace referencia al "zelo, actividad y desinterés de nuestros Españoles y, con especialidad, del Serenísimo Señor don Juan de Austria..." ${ }^{\prime 31}$.

Jerónimo Corte Real se basó en diferentes descripciones, reseñas de ejércitos y relaciones para la creación del discurso narrativo e iconográfico de su libro; es probable que el autor portugués consultase aquellas obras que unos años antes habían salido a la luz como la relación de fiestas que la ciudad de Sevilla tributó al vencedor de Lepanto, escrita por Pedro de Oviedo e impresa en Sevilla en $1572^{32}$, la Relacion de la gverra de Cipre y svcesso de la batalla Naual de Lepanto impresa en el mismo año, también en Sevilla, por Fernando de Herrera o la descripción de Ambrosio de Morales titulada Descriptio belli nautici et expugnatio Lepanti per D. Joannum Austria, reproducida en el tomo XXI de la Colección de Documentos Inéditos para la Historia de España ${ }^{33}$.

En todo caso, los retratos de los generales griegos, los reyes espartanos y los bustos de los sultanes otomanos eran frecuentes en las colecciones de miniaturas y de grabados que circulaban por la Europa del siglo XVI. Estas efigies habían sido el modelo para las ilustraciones de las Elogia de Paolo Giovio, sobre todo, para la creación iconográfica de los retratos de Mahomet II y del emperador turco Solimán ${ }^{34}$; una moda que Corte Real pudo haber tomado como referencia para sus estampas librescas.

Por otro lado, la numismática se convierte en otro de los instrumentos fundamentales de transmisión de ideas, valores y símbolos que el
Renacimiento supo aprovechar para la creación de sus retratos ${ }^{35}$. Las medallas más difundidas a lo largo del siglo XVI son las de dirigentes políticos y militares. En este sentido, resulta lógico que sean estas obras las que influyan, de modo directo, en la creación de los tipos iconográficos de las ilustraciones de obras como la de Felicissima Victoria. La representación del retrato de perfil y sus motivos iconográficos es prueba evidente de ello. Asimismo, la literatura emblemáti$\mathrm{ca}$, que el autor portugués conoce, así como las artes figurativas del Renacimiento, constituyen otras de las fuentes principales para el estudio de esta obra apologética.

Una simbiosis del mundo clásico y del medieval que, al modo petrarquesco, permite la comprensión de retratos como el de Alí Bajá, Selim o el propio Juan de Austria en el canto VII (Fig.5). En éste vemos al héroe de Lepanto recibiendo el estandarte de la Santa Liga. No podemos olvidar que Felipe II había nombrado a su hermano Juan de Austria "capitán general de la Mar" en el año 1568, encargándole esta ardua tarea como un servicio a Dios y a la Iglesia "contra los turcos infieles que infestan la mar, puertos y costas de la cristiandad"36.

En Nápoles, Juan de Austria recibe el estandarte de la Santa Liga de manos del cardenal Granvela, con la decoración de las armas del Papa, las de España y las de Venecia. Encima

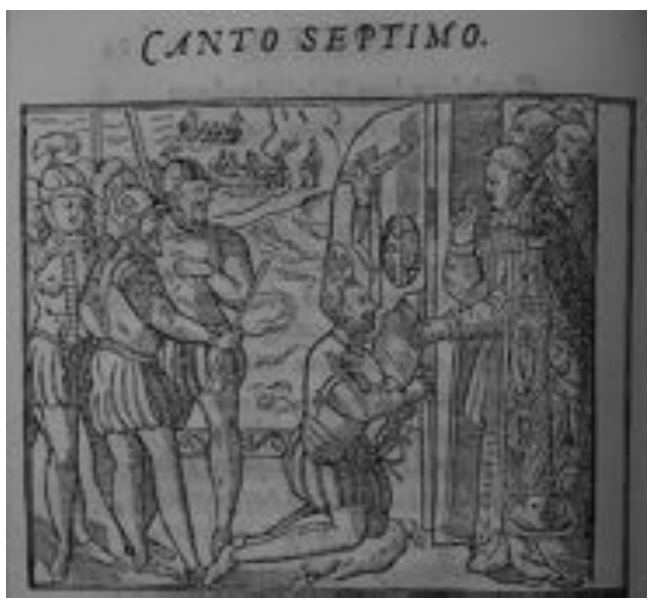

Fig. 5. Canto VII, Juan de Austria recibiendo el estandarte de la Santa Liga. Jerónimo Corte Real, Felicissima Victoria, Lisboa, 1572 
de los emblemas heráldicos se representaba a Cristo en la cruz. Así nos lo explica el texto que acompaña al grabado:

En este septimo canto, el señor Don Juan D’Austria llega a Génova, de ay vá la via de Napoles: recibe el estandarte de la Liga de mano del cardenal Granvela y apercibido de municiones y vituallas toma el puerto de Me$\sin a^{37}$.

Un escudo que ya decoraba los impresos de la época, como la Crónica del Príncipe don Juan de Austria de Jerónimo de Costiol, impreso en Barcelona en el año $1572^{38}$ y una imagen que retoma la iconografía numismática y que se repite en las representaciones medievales y renacentistas. En este sentido, la ceremonia de entrega de la obra del autor al mentor y mecenas de la misma, se convierte en una escena frecuente en los frontispicios de la primera mitad del siglo XVI; la Vita Christi Cartuxano de Ludolphus de Saxonia, impresa en Alcalá de Henares en 1503, con la imagen del autor entregando su libro a los Reyes Católicos ${ }^{39}$, es un claro ejemplo de ello.

Parece, por tanto, evidente que los escudos y los símbolos heráldicos desempeñan una función notable en la iconografía de las imágenes de Felicissima victoria; en el canto X (Fig. 6) don Juan de Austria prepara su flota para partir hacia Cefalonia mientras es avisado por un habitante de Famagusta de la destrucción de la ciudad por los turcos ${ }^{40}$; la presencia de la galera real es la protagonista de esta nueva ilustración. La falta de datos iconográficos para la recomposición de la galera, generó la circulación de grabados que representaban la nave sin una decoración que se ajustase al modelo original. Tampoco el poema del portugués contribuyó a aclarar los motivos decorativos de la embarcación. La única fuente que permite conocer la decoración de la nave es la Descripción de la Galera Real del Sermo. Sr. D. Juan de Austria de Juan de Mal Lara, obra que no fue editada hasta 1876. En ella, el humanista sevillano hace gala de todo un conjunto de motivos iconográficos que le acercan a las narraciones mitológicas de la literatura clásica, a las obras de Platón, Plinio y Aristóteles, sin olvidar las fuentes coetáneas como el Emblematum Liber de Alciato o los Hieroglyphica de Piero Valeriano ${ }^{41}$.

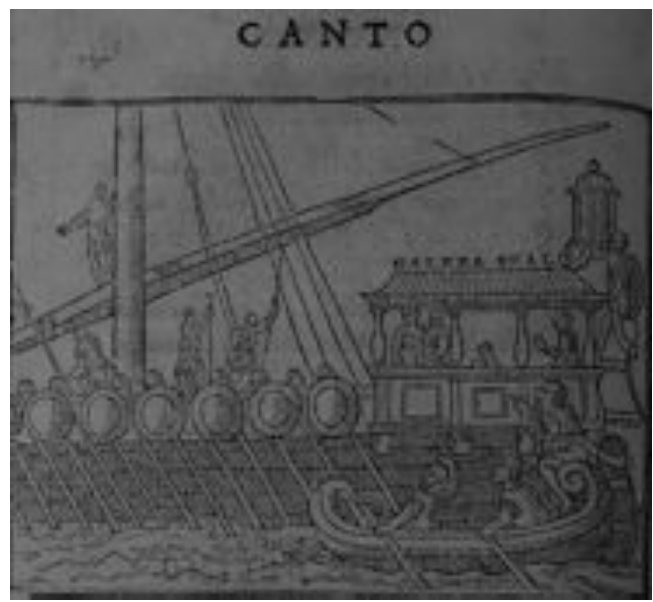

Fig. 6. Canto X, La Galera Real. Jerónimo Corte Real, Felicissima Victoria, Lisboa, 1572

Al margen de otras consideraciones, lo que sí resulta evidente es que los grabados que ilustran Felicissima victoria recogen, de alguna manera, la esencia que había caracterizado el programa iconográfico de la galera real de don Juan de Austria. La presencia de Vulcano, Neptuno y Marte son algunos de los personajes mitológicos que se representan en la nave real.

En este sentido, parece lógico afirmar, que la recuperación de personajes de la mitología clásica se convirtió -en las obras de época moderna $y$, en especial, en aquellas de temática políticaen la herramienta fundamental para la transmisión de los valores imperialistas de la Universitas Christiana de la Monarquía de los Austrias ${ }^{42}$. Un concepto de monarquía universal y extirpadora de herejías que está presente no sólo en los programas iconográficos de las obras de arte sino también en los impresos de la época.

Del mismo modo, no es casualidad que Proteo, dios del mar, profetice la victoria cristiana en el canto XII (Fig. 7). Corte Real lo acompaña de este texto:

En este duodecimo canto se mueven muchos pareceres: unos que se busque la armada de los Turcos, otros que de alli luego se devian bolver. Al fin el señor Don Juan d'Austria se delibera dar la batalla y resoluto en este acuerdo la busca. Proteo prophetiza el sucesso de la armada Christiana... ${ }^{43}$. 


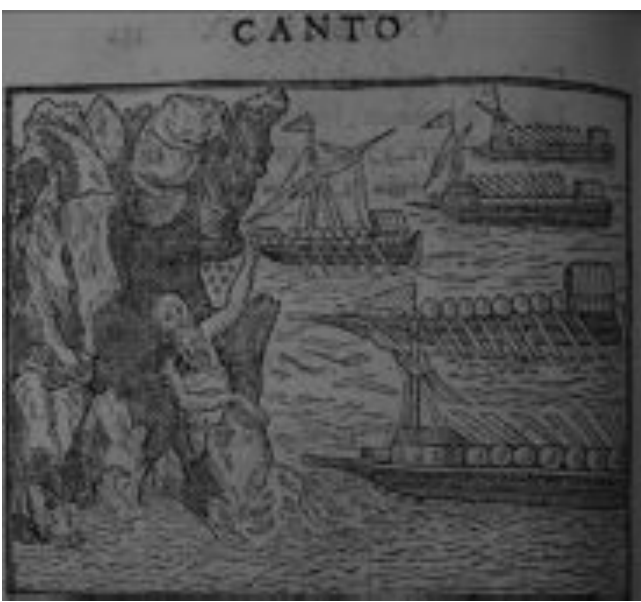

Fig. 7. Canto XII, Proteo vaticina la victoria cristiana. Jerónimo Corte Real, Felicissima Victoria, Lisboa, 1572

Una de las misiones de Proteo era alimentar bajo las aguas las focas y los becerros marinos que formaban parte del rebaño de Neptuno. Para recompensar su celo este dios le había concedido el privilegio de conocer el pasado, el presente y el porvenir: "el tiempo no tenía para él secreto alguno"44. La batalla estaba, por tanto, del lado de la Santa Liga. Corte Real no dudó, en ningún momento, en incluir a Proteo como uno de los protagonistas de la estampa pues su presencia sólo corrobora la moraleja a la que hace referencia Humbert cuando habla del dios del mar:

Esta fábula alegórica nos enseña que aquellos que quieren desentrañar los secretos de la naturaleza, profundizar los problemas de las artes y de las ciencias, llegar, en una palabra, al conocimiento de la verdad, han de consagrarse a ello con decidido entusiasmo y sin dejarse jamás abatir por los obstáculos: la lucha les será, al fin, favorable y provechosa y el éxito coronará sus esfuerzos ${ }^{45}$.

Ahora bien, en Felicissima Victoria, los dos grandes protagonistas mitológicos son, sin lugar a dudas, Venus y Marte. Su presencia en la literatura clásica y en el arte imperial tuvo una gran difusión pues en muchas de las leyendas sobre la fundación de Roma, Marte era considerado el padre de los gemelos Rómulo y Remo con- virtiéndose, por consiguiente, en antepasado de los romanos. Numa Pompilio erigió, en honor a Marte, un colegio de doces sacerdotes -salioscuya función principal era custodiar y conservar los escudos sagrados. Venus, diosa del amor, era considerada también por los romanos una diosa Victoriosa y se acompañaba de atributos alusivos al triunfo:

Tambien llamaron los Griegos y Romanos à la Diosa Venus Victoriosa, como à lupiter y Marte victoriosos: poniendole en la mano derecha la Victoria y en la yzquierda un çeptro y el braço apoyado sobre un gran escudo... ${ }^{46}$.

En el programa iconográfico del Foro de Augusto Marte representaba la virtus y Venus la abundancia y la fecundidad ${ }^{47}$.

Corte Real se aprovechó de las obras clásicas y de estas interpretaciones alegóricas para componer sus grabados librescos. En el discurso narrativo de la obra, el autor portugués va relatando en cada uno de los cantos los acontecimientos de la batalla. Después de los sueños de Selim y Alí Bajá en los cantos I y IV, los cantos II, III y $\vee$ se aprovechan para narrar la conquista turca de Chipre y el saqueo de Candía, Zante y Cátaro. Este último canto le sirve a Jerónimo Corte para la introducción de los dioses del Olimpo. De este modo, en el canto VI (Fig. 8), Venus, dolida con los turcos por la destrucción de su reino, es informada de la conformación de la Santa Liga y, a pesar de predecir el futuro victorioso de la armada cristiana, la diosa decide proteger a don Juan de Austria y le encarga a su marido, Vulcano, la fabricación de unas armas. Ésta es la imagen que aparece en esta ilustración: Vulcano hace las armas al joven don Juan y en "el escudo dibuxa todas las victorias del Emperador Carlos Quinto y del magnanimo Philippe Rey de España"48.

Las fuentes de este VI canto están tomadas de la Eneida de Virgilio; en ésta se describe la batalla de Actium que será tomada como referencia para la obra no sólo de Felicissima victoria sino para gran parte de escritos que sobre Lepanto se publicaron en el último tercio del siglo XVI. La batalla de Actium se describe en la cuarta y última profecía del poema, a modo de colofón, 


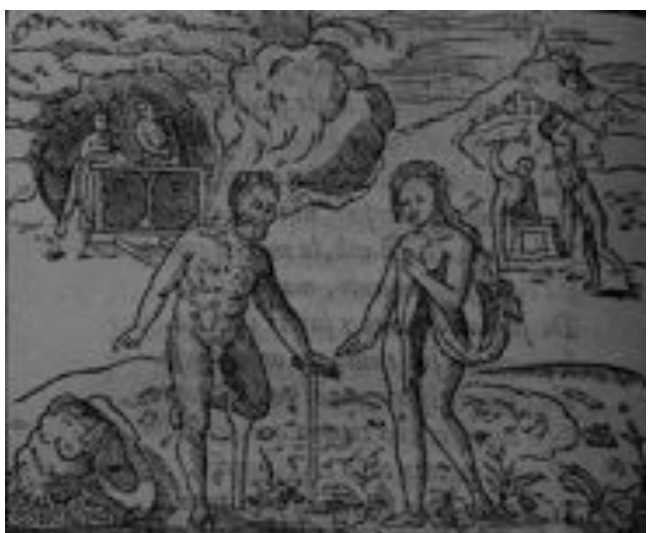

Fig. 8. Canto VI. Venus y Vulcano. Jerónimo Corte Real, Felicissima Victoria, Lisboa, 1572

donde la historia de Roma termina en el escudo que el dios Vulcano ha fabricado para Eneas, a petición de Venus; una crónica que retoma la descripción del escudo de Aquiles en la llíada de Homero ${ }^{49}$.

La épica del Renacimiento y, en concreto la obra de Jerónimo Corte Real, echó mano de las obras clásicas con el fin de enlazar la historia del imperio hispano -el de Felipe II- con el imperio romano. La huella virgiliana la encontramos nada más empezar a leer el primer verso del canto Vl: "Canto con alta voz, canto la fuerza, el ímpetu furioso, osado y fiero, de la cristiana gente, el vencimiento de la armada otomana aquí rendida"; después de todo, la presencia de las profecías que, en el caso de la Eneida, permitía a Virgilio vincular los sucesos de la historia romana con pasajes simbólicos y providencialistas, es un elemento recurrente en la obra del erudito portugués; además, no podemos olvidar que la incorporación de escenas mitológicas que interrumpen la sucesión de los hechos acaecidos, había sido un recurso utilizado por autores de la época, como Camões, en especial, en Os Lusíadas, epopeya en la que es muy probable que Corte Real se haya también inspirado ${ }^{50}$.

La iconografía de este pasaje y la inclusión de los dioses mitológicos responden al fin último de la obra de Felicissima Victoria: ensalzar la figura del monarca Felipe II y de Juan de Austria como férreos defensores de la cristiandad, convirtiendo a Lepanto en la "gesta personal del rey, de la que su hermano es un digno y leal ejecutor" $"$.

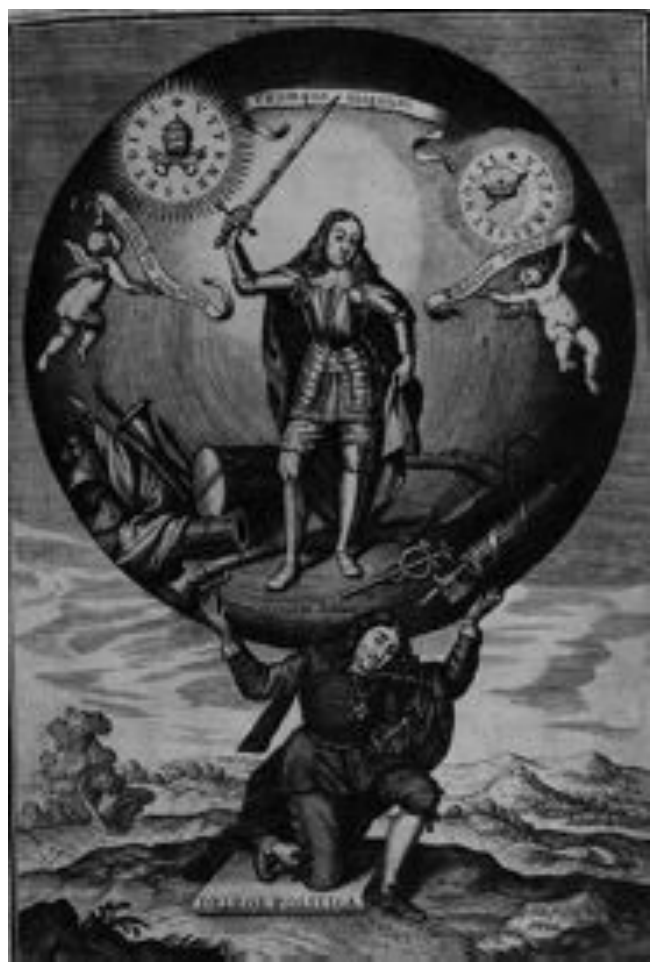

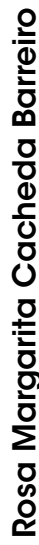

Fig. 9. Retrato de Carlos II. Pedro González de Salcedo, De Lege Politica, Madrid, 1678

Lara Vilà, en referencia a este pasaje de la Eneida, añade:

Así pues, la ecphrasis del escudo no es únicamente una recensión de la historia de Roma sino del mundo entero y el gesto final de Eneas, que acepta el regalo materno y carga a sus espaldas el futuro de los suyos, le convierten en un nuevo Atlante, que asume el control del mundo para cederlo a la raza nacida de su persona, los romanos, a perpetuidad $^{52}$.

Esta idea del atlante como elemento sostenedor de un imperio, está muy presente en las estampas librescas de la monarquía de los Austrias $^{53}$. Así lo vemos en la obra de Pedro González de Salceda titulada De Lege Politica eiusque Naturali Executione et Obligatione, tam inter laicos quam eclesiásticos ratione... impresa en

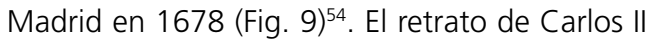
con una espada alzada en su mano protagoniza 
la imagen central. La efigie del monarca se enmarca dentro de un gran círculo que está siendo sostenido por su primer ministro y hermanastro Juan José de Austria.

El motivo de Atlas sustentando la bola del mundo es recurrente en la emblemática de los siglos XVI y XVII; en las empresas militares de Paolo Giovio se representa con el mote Sustinet nec fatiscit $t^{55}$ y en la Emblemata amorosa de Vaenius con el lema Atlante maior ${ }^{56}$ y el epigrama "Sustentó al cielo el poderoso Atlante y Hércules que le hizo compañía, que en uno nadie vio poder bastante para acabar tan grande valentía" 57 .

También en las empresas morales de Borja nos encontramos con la imagen de Atlas que sostiene la bola del mundo y que se acompaña del mote: Leve et momentaneum ("liviano y de poca dura") y en cuyo texto se alude a la idea de la recompensa por el sufrimiento de cargar con los trabajos, los problemas y las opresiones mundanas ${ }^{58}$.

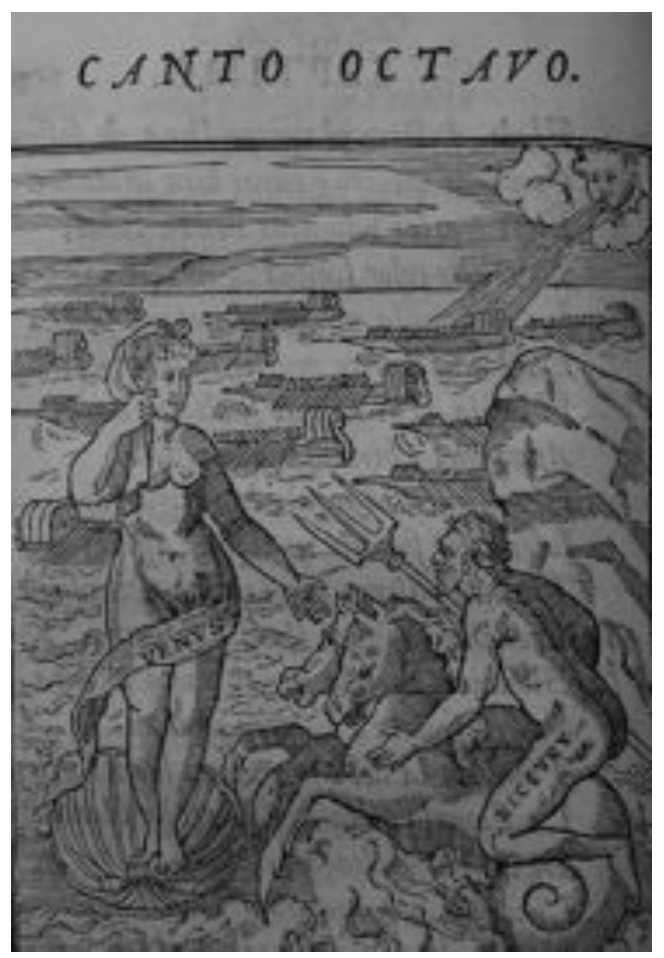

Fig. 10. Canto VIII, Venus y Neptuno. Jerónimo Corte Real, Felicissima Victoria, Lisboa, 1572
Por otro lado, en las exequias de Felipe IV en Zaragoza se representa la imagen del monarca como Atlas, con el mote Viribus inferior mole probatur Atlas ${ }^{59}$, estableciéndose un paralelismo entre Hércules y el rey como sustento de la monarquía española. Esta misma relación aparece en la portada del libro de González de Salcedo en donde es el propio Juan José de Austria el que ejerce la función de sustentar la pesada carga del gobierno representado por Carlos II.

Con todo, la imagen de Venus vuelve a aparecer en el octavo canto de Felicissima victoria (Fig. 10): en él se resume cómo la diosa, una vez más, vuelve a interceder por la flota cristiana pues el Bóreas sopla con fuerza y dificulta el avance de las tropas de don Juan de Austria. Para ello acude a Neptuno y le pide que interceda a favor de la Liga cristiana. Neptuno avisa a Tritón para que calme las olas y Venus pedirá a Eolo que detenga los vientos, una imagen, por otra parte, presente en la literatura emblemática pues ya Juan de Borja, en sus empresas morales, nos muestra un árbol sacudido por vientos contrapuestos con el lema Con los contrastes se hace más fuerte en relación a la firmeza de la virtud. En el canto noveno (Fig. 11), Venus desciende del cielo en una nube para entregarle las armas a don Juan y anunciarle su futura victoria en el golfo de Lepanto.

El libro de Corte Real termina con una apoteosis final que queda perfectamente reflejada en el grabado que ilustra el último canto (Fig. 12) con la presencia de las ninfas del mar que,

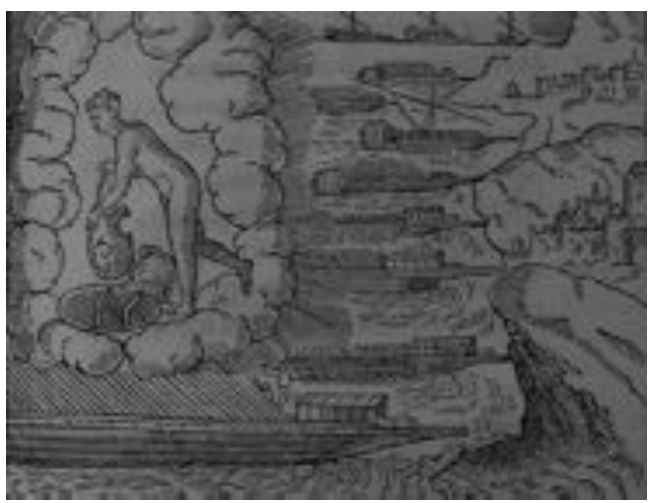

Fig. 11. Canto IX, Venus entrega las armas a Juan de Austria. Jerónimo Corte Real, Felicissima Victoria, Lisboa, 1572 


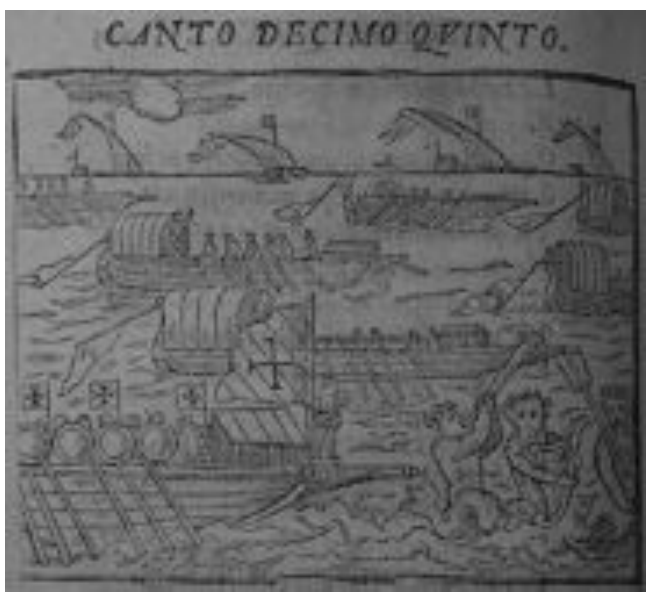

Fig. 12. Canto XV, Las ninfas del mar haciendo sonar sus instrumentos. Jerónimo Corte Real, Felicissima Victoria, Lisboa, 1572

dirigiéndose a los héroes de la batalla, hacen sonar sus instrumentos, mientras cantan: "Felicísima planta gloriosa, del invencible Carlo tan temido, por haber emulado sus gestas y a Lepanto como la más célebre victoria naval jamás conseguida" 60 .

\section{CONCLUSIÓN}

La Invencible y su Lepanto. Solo el nombre de esta batalla nos trae a la memoria el cruento choque de civilizaciones que en el pasado enfrentó al Islam y la cristiandad. Un momento dramático en el que el destino de Occidente se jugó a una sola carta.... Fue una victoria colosal. En toda Europa se tuvo la sensación de que el invencible Imperio Otomano había sido frenado en su imparable avance hacia el Oeste ${ }^{61}$.

La batalla de Lepanto, más allá de servir de unidad de la cristiandad ante la amenaza turca, se convirtió en el refuerzo de poder del mundo católico tras la escisión protestante. Una bataIla contra los infieles que llevó a Francis Bacon a destacar la labor llevada a cabo por Pío $V$ en el combate de Lepanto: "No hay mayor empresa, al día de hoy, ni honor terrenal más importante que guerrear contra infieles"62. Una representación del infiel que quedará de manifiesto en los diversos grabados que ilustraron las obras a lo largo de la época moderna. El infiel y la herejía son motivos iconográficos constantes en los frontispicios librescos, simbolizando el triunfo del bien sobre el mal y de la virtud sobre el pecado; de este modo se representa en la portada del Theatrum de Cristóbal de Santotís (1607) o en el Concilio Generalia et Provincialia, impresa en 1606. En ellas, la alegoría de la Iglesia, representada en la parte inferior, da muerte a la herejía personificada, en el primer frontispicio, a partir de una serie de figuras pisoteadas y aplastadas en el centro del basamento y, en el segundo, a partir de la Envidia y el Furor que están siendo encadenados y sometidos por la Iglesia.

El hereje es, a la luz de estas consideraciones, el turco, arquetipo demoníaco, que acosa e invade las costas españoles con "su estela de cautivos y renegados" 63 pues "no hay cosas natural à los turcos, que la tirania, la crueldad, y la violencia..." 64 .

El cristiano, por el contrario, imagen de obediencia y magnanimidad, será el protagonista de la batalla lepantina, encarnado en las figuras de Felipe II y Juan de Austria, alegorías de la Universitas Christiana, que refleja el lenguaje universalista e imperialista de la Monarquía de los Austrias. El joven Austria se muestra, en Felicissima victoria, como el heredero de los emperadores romanos; a ello contribuyen la presencia y las acciones de las figuras mitológicas: Venus como engendradora del bien y de la victoria, quien, a través de sus súplicas, consigue el escudo que le defenderá; también Marte, como dios de la victoria, ampara a la armada cristiana pues él mismo había sido nombrado por el emperador Numa Pompilio protector de templos y de escu$\operatorname{dos}^{65}$.

En definitiva, una tradición clásica que se presenta como norma estética y política, impuesta por el Estado a todas las técnicas artísticas tomadas en su colectividad. Una tradición que tiene por función traducir en imágenes el cuerpo imaginario del rey, a través de las referencias mitológicas y de las hazañas que se ponen, en el caso de Felicissima victoria, al servicio de la propaganda monárquica"66. Una llamada constante a la literatura y a la iconografía clásica que se repite a lo largo de la obra y que aparece ya en la primera de las ilustraciones con la alegoría 
del Sueño, la presencia de la Guerra y la referencia al Infierno, tan presente en las obras de Claudiano y de Virgilio: "En este primer canto sale la guerra del infierno, en sueños persuade Selim, emperador de los Turcos que conquiste à Cipro" 67 .

Por otro lado, la Felicissima Victoria no se aleja de las características propias de los relatos de sucesos de los siglos XVI y XVII. En éstos el discurso narrativo nos presenta un esquema claro y predeterminado: En primer lugar, se narran las circunstancias de los hechos -el sueño de Selim persuadido por la Guerra para que ataque a la Cristiandad en el canto I, el sueño de Alí Bajá donde se le aparece el templo de Marte y le anuncian la batalla de Lepanto, en el cuartoa continuación, la preparación del encuentro -cantos sexto a décimo tercero- y, por último, el enfrentamiento y la derrota de los enemigos -cantos $n^{\circ} 14$ y n० 15-. Asimismo, la descripción pormenorizada de los acontecimientos es otro de los rasgos típicos de estos impresos ${ }^{68}$; en el canto $n^{\circ} 14$ Jerónimo Corte describe las heroicidades de diversos héroes cristianos "se señalan algunos capitanes, y cavalleros, ofreciendo las vidas por la Christiana Fee, ganan fama y renombre eterno al mundo..." 69 .

Asimismo, la claridad de las escenas y el orden de los elementos presentados nos acercan al arte compositivo de finales del siglo XV y principios del siglo XVI. En este sentido vemos cómo los protagonistas de la armada turca se dan la mano en el canto IV, una imagen que permite al autor del libro generar una línea de fuga que nos lleva al fondo de la escena; la profundidad se logra a partir de la oquedad que nos dejan las hornacinas laterales y el pedestal sobre el que se elevan Marte y don Juan de Austria, en el plano de fondo. Un sistema compositivo que se repite en las escenas marítimas con la presencia poderosa y jerárquica de las galeras cristianas frente a las fragatas turcas, identificadas con emblemas, en los cantos XIII y XIV.

Desde el punto de vista arquitectónico, los grabados de principios de siglo XVI adquieren una mayor solidez y un sentido de la perspectiva cada vez más desarrollado, que permite abandonar la noción de la frontalidad que había dominado hasta el momento; se nos presenta, por tanto, la idea de la estampa como "una ventana abierta" sobre la que se aplican aquellos conceptos ilusionísticos que artistas como Alberti habían teorizado la centuria anterior ${ }^{70}$. Las escenas de Felicissima victoria se ajustan a estos cánones de proporción, equilibrio y simetría; concibiendo, en definitiva, la escena con un enmarque perspectivo y un enfoque medianamente realista.

La emblemática y los grabados no dejan de ser los modelos a los que el autor recurre a la hora de idear el programa iconográfico de las estampas. En otro de los libros de Corte Real, el Sucesso do segundo cerco de Diu, vemos cómo el sueño que tiene el rey de Cambaya -donde se le incita a cercar la fortaleza de Diu y a destruir la superioridad marítima de Portugal en el Océano Índico ${ }^{71}$-, se relaciona directamente con la imagen de Selim en el canto I de Felicissima victoria; el concepto es el mismo y la iconografía se repite en ambos grabados. Lo mismo ocurre en otra de las imágenes del Sucesso do segundo cerco de Diu, con la aparición victoriosa de las ninfas en el mar que ya se presentaba en el último canto de Felicissima victoria.

De este modo, la fabricación de los escudos por parte del dios Vulcano vuelve a ser una imagen frecuente en las ilustraciones de obras como Le imagini de i Dei de Vincenzo Cartari o en pinturas tan conocidas como La fragua de Vulcano de Velázquez.

En definitiva, los versos, las ilustraciones y los relatos mitológicos de Felicissima Victoria tienen el objeto, como afirma Larà Vilà de

otorgar a la inminente victoria de Lepanto un carácter simbólico no solo como la gesta que culmina el poderío austríaco y español en el mundo, sino también como instrumentalización del concepto de la translatio imperii, para hacer de España, a través del modelo de la Eneida, la heredera del Imperio Romano y de Felipe II el sucesor de un linaje de emperadores universales que se inició con Octavio Augusto ${ }^{72}$. 


\section{NOTAS}

1 Conferencias sobre Lepanto: 1547-1947. Madrid, 1947-1948. Matilde LÓPEZ SERRANO, "Lepanto en sus representaciones grabadas", en Reales Sitios, 29 (1971), p. 12.

Fernando MARÍAS, "Una estampa con el arco triunfal de Don Juan de Austria (Messina, 1571): desde Granada hacia Lepanto", en Lexicon. Storia e architettura in Sicilia, 5-6 (2007-2008), pp. 65-74.

Víctor MíNGUEZ, "Iconografía de Lepanto. Arte, propaganda y representación simbólica de una monarquía universal y católica", en Obradoiro de Historia Moderna, 20 (2011), pp. 251 280.

2 Paulina JUNQUERA, "La batalla de Lepanto en el arte de su tiempo", en Reales Sitios, 29 (1971).

${ }^{3}$ Carmen GARCÍA-FRÍAS CHECA, "Las series de batallas del Real Monasterio de San Lorenzo de El Escorial. Frescos y pinturas", en La imagen de la guerra en el arte de los antiguos Países Bajos. Bernardo J. García García (ed.), Madrid, Editorial Complutense, 2006, pp. 143-145.

${ }^{4}$ Rafael Alberto ACEVEDO, Poesías escogidas de Herrera, Rioja, los Argensolas y Villegas. Madrid: imprenta de Sancha, 1822, pp. 15 y ss.

${ }^{5}$ José Jaime GARCíA BERNAL, "Velas y estandartes: imágenes festivas de la batalla de Lepanto", en Revista Científica de Información y Comunicación (2007), pp. 172-211.

${ }^{6}$ Miguel de CERVANTES SAAVEDRA, El ingenioso hidalgo don Quijote de la Mancha, vol. 4, Madrid: Oficina de E. Aguado: 1835, p. VI.

7 F. Javier CAMPOS Y FERNÁNDEZ DE SEVILLA, "Cervantes, Lepanto y el Escorial (Nueva interpretación de la historiografía clásica sobre la relación existente entre la batalla naval y el Monasterio, a la luz de los documentos de la época y del propio testimonio de Cervantes", en Volver a Cervantes. Actas del IV Congreso Internacional de la Asociación de Cervantistas. T.I. Antonio Bernat Vistarini (ed.), Palma, Universitat de les Illes Balears, 2001.

${ }^{8}$ Mi más sincero agradecimiento al Dr. James Nelson Novoa, Postdoctoral fellow \& Lecturer. Fundação para Ciência e Tecnologia de Portugal. Cátedra de Estudos Sefarditas "Alberto
Benveniste", de la Universidad de Lisboa, por los datos aportados en relación a la literatura lepantina del siglo XVI.

9 José FERNÁNDEZ DE LA PUENTE, Memoria histórico-crítica del célebre combate naval. Madrid: Imprenta de A. Vicente: 1853

10 Lara VILÀ, "Historia verdadera" y propaganda política: La Felicísima victoria de Jerónimo Corte Real y el modelo épico de Virgilio, en Res Publica Litterarum. Documentos de trabajo del Grupo de investigación "Nomos". Madrid, Instituto Lucio Anneo Séneca, 2005

11 Marscha SWISLOCKI: "En las fronteras del imperio: Jerónimo Corte Real y la épica luso-castellana", en El Siglo de Oro en escena. Homenaje a Marc Vitse. Toulouse, PUM, Consejería de Educación de la Embajada de España en Francia, 2006, p. 1001.

12 Jerónimo CORTE REAL, Felicissima victoria concedida del cielo al señor don Juan de Austria, en el golfo de Lepanto de la poderosa armada otomana, en el año de nuestra salvación de 1572. Lisboa: Antonio Ribero: 1578, s.p.

13 José Jaime GARCÍA BERNAL: "Imaginario político del Mediterráneo en la Relación de las suntuosas y ricas fiestas de Pedro de Oviedo", en Pierre Civil, Françoise Crémoux et.al (ed.), España y el mundo mediterráneo a través de las relaciones de sucesos (15001750). Salamanca, ediciones Universidad de Salamanca, 2008, p. 206.

${ }_{14} \mathrm{M}^{\mathrm{a}}$ Rosa ÁlVAREZ SELLERS (ed.): Literatura portuguesa y literatura española: influencias y relaciones. Valencia, Departamento de Filología Española, Universitat de València, 1999, p. 25

15 Jerónimo CORTE REAL, Felicissima victoria... op.cit. $\mathrm{p}$.

${ }^{16}$ Miguel Ángel ELVIRA BARBA: Arte y mito: manual de iconografía clásica. Madrid: Sílex, 2008, pp. 141-143.

17 Marisol VILLARRUBIA, "Sueños, ensueños y apariciones en el Purgatorio de Dante. Su función estructural y significativa", en Societat catalana d'Estudios Dantescos, n 1 (2000), pp. 137-158. Summa II-II, c. 95.

18 Pedro A. GALERA ANDREU, "Iconografía del sueño. Persistencias clásicas en el Sueño de Jacob de Ribera", en Cuadernos de Arte e Iconografía, T. II, n 3 (1989), p. 292
19 Guy de TERVARENT, Atributos y símbolos en el arte profano. Diccionario de un lenguaje perdido. Barcelona, Ediciones del Serbal, p. 25

${ }^{20}$ Miguel Ángel ELVIRA BARBA, Arte y mito... op.cit. pp. 141-143.

${ }^{21}$ Eric M. MOORMANN \& Wilfried UITTERHOEVE, De Acteón a Zeus: temas de mitología clásica en literatura, música, artes plásticas y teatro. Madrid, Akal, 1997, p. 193.

22 Juan HUMBERT, Mitología griega y romana. Barcelona, Gustavo Gili, 1994, p. 53.

${ }^{23}$ Jerónimo CORTE REAL, Felicissima Victoria...op.cit. p. 186.

${ }^{24}$ Ricardo GARCÍA CÁRCEL, "La psicosis del turco en la España del Siglo de Oro", en Los Imperios orientales en el teatro del Siglo de Oro. Felipe B. Pedraza Jiménez y Rafael González Cañal (eds.). Ciudad Real, Universidad de Castilla la Mancha, 1994, p. 17.

25 Pierre CIVIL, "Las relaciones de batallas navales en el Mediterráneo (siglos XVI y XVII): Estrategias narrativas", en Encuentro de Civilizaciones (1500-1750): Informar, narrar, celebrar. Actas del III Coloquio Internacional sobre Relaciones de Sucesos. Alcalá de Henares, Universidad de Alcalá, 2003, pp. 106-107.

${ }^{26}$ Ricardo GARCÍA CÁRCEL, "La psicosis del turco en la España del Siglo de Oro" ... op.cit. p. 17.

27 Jerónimo CORTE REAL, Felicissima Victoria... op.cit. p. 49.

${ }^{28}$ Guillaume DE CHOUL, Discursos de la religion, castramentaçion assiento del Campo, Baños y exerçiçios de los Antiguos Romanos y Griegos, León de Francia: Guillermo Rovillio: 1579, pp. 227-228.

29 José Jaime GARCÍA BERNAL, "Velas y estandartes...", op.cit. p. 195.

30 José Jaime GARCÍA BERNAL, "Velas y estandartes..." op.cit. p. 195.

${ }^{31}$ Ambrosio de MORALES, Opuscula Historica, quorum exemplaria in R.D. Laurentii Bibliotheca Vulgo del Escorial custodiuntur. Madrid: Ex typographia benedicticano: 1793, p. 7

${ }^{32}$ Pedro DE OVIEDO, Relacion de las sumptuosas y ricas fiestas, que la insigne ciudad de Sevilla hizo, por el felice nascimiento del principe nuestro señor. Y por el vencimiento de la bataIla naual, que el serenissimo de Austria 
ouo, contra el armada del Turco. SeviIla: Hernando Díaz: 1572.

33 José Jaime GARCÍA BERNAL: "Velas y estandartes...", op.cit. p. 180.

34 P. MICHEL-LOJKINE, Le Siècle des Grands Hommes. Les recueils de Vies d'hommes illustres avec portraits du XVI siècle, Louvain-Paris, 2001, p. 411-414. M. E. MÜNTZ, "Le Musée de portraits de Paul Jove. Contributions pour servir à l'iconographie du Moyen Âge et de la Renaissance", en Mémoires de l'Institut nationale de France. Académie des Inscriptions et Belles-lettres 36, 2 (1900), p. 260.

${ }_{35}$ Prueba de ello es la carta que Aretino escribe al escultor Leon Leoni en 1549: "(..) No me regocijo en vos del favor en que os tiene el Emperador, más bien me felicito con su Majestad en la estima que ella hace del mérito. Las medallas que deben dar la inmortalidad a su nombre valen mucho más que las recompensas cualquiera que ellas sean, que recibís por ello (...). F. CHECA CREMADES, Carlos $V$ y la imagen del héroe en el Renacimiento, Madrid, 1987, p. 89.

36 Sylvène EDOUARD, "Argo, la galera real de Don Juan de Austria en Lepanto", en Reales Sitios. Revista de Patrimonio nacional, año XLIV, $n^{\circ} 172$, (2007), p. 6.

37 Jerónimo CORTE REAL, Felicissima Victoria... op.cit.

38 Sylvène EDOUARD, "Argo, la galera real de Don Juan de Austria en Lepanto"... op.cit. p.7

${ }^{39}$ Fernando CHECA CREMADES, "La imagen impresa en el Renacimiento y el Manierismo", en El Grabado en España (siglos XV-XVIII), Summa Artis, vol. XXXI, Madrid, 1992, pp. 14-15.

${ }^{40}$ Lara VILÀ: "Actium y Lepanto en la épica española del siglo XVI: La Felicísima Victoria de Jerónimo Corte Real", en Salina, nº 18 (2004), p. 84.

${ }^{41}$ Sylvène EDOUARD, "Argo, la galera real de Don Juan de Austria en Lepanto"... op.cit. pp. 7-8.

42 Jean SEZNEC, Los dioses de la Antigüedad en la Edad Media y Renacimiento, Madrid, Taurus, 1983.

Jesús Ma GONZÁLEZ DE ZÁRATE, Mitología e Historia del Arte, Madrid, Encuentro, 2012.
43 Jerónimo CORTE REAL, Felicissima Victoria... op.cit. p. 152.

44 Juan HUMBERT, Mitología griega y romana... op.cit. p. 100.

45 Juan HUMBERT, Mitología griega y romana... op.cit. pp. 100-101.

${ }^{46}$ Guillaume DE CHOUL, Discursos de la religión... op.cit. 229.

47 Paul ZANKER, Augusto y el poder de las imágenes. Madrid, Alianza Editorial, 1992, p. 233.

48 Jerónimo CORTE REAL, Felicissima Victoria... op.cit. pp. 266-272.

49 Lara VILÁ: "Actium y Lepanto en la épica del siglo XVI...", op.cit. pp. 80-82.

50 Jerônimo CORTE REAL: Poesia. Hélio J.S. Alves (ed.). Braga-Coímbra, Angelus Novus editora, 1998, pp. XXXVIII-LIII.

51 Lara VILÀ, "Historia verdadera" y propaganda política...", op.cit. pp. 1-16

52 Lara VILÀ, "Historia verdadera" y propaganda política...", op.cit. pp. 1-16

${ }^{53}$ Teresa ZAPATA FERNÁNDEZ DE LA HOZ, "Atlas-Hércules. Metáfora del poder y gobierno de los Austrias", en Emblemática Trascendente, hermenéutica de la imagen, iconología del texto, Pamplona, Universidad de Navarra, 2001.

${ }^{54}$ Rosa Margarita CACHEDA BARREIRO: La portada del libro en la España de los Austrias Menores. Un estudio iconográfico. Tesis Doctoral. Universidad de Santiago de Compostela, 2006.

\footnotetext{
55 "Resiste y no decae".

56 "Más fuerte que Atlas".
}

57 Santiago SEBASTIÁN LÓPEZ: La mejor emblemática amorosa del Barroco. Heinsius, Vaenius, y Hoof. Ferrol, Sociedad de Cultura Valle-Inclán, 2001, pp. 66-67.

58 Antonio BERNAT VISTARINI; John T. CULL: Enciclopedia Akal de Emblemas Españoles ilustrados. Madrid, Akal, 1999, p. 114.

59 "Atlas inferior en fuerzas fue probado por la mole del mundo".

${ }^{60}$ Lara VILÀ; "Actium y Lepanto en la épica del siglo XVI ...", op.cit. p. 86.
61 Manuel RIVERO RODRíGUEZ, La batalla de Lepanto: cruzada, guerra santa e identidad confesional, Madrid, Sílex, 2008, p. 295.

62 Manuel RIVERO RODRÍGUEZ, La batalla de Lepanto... op.cit. pp. 295296.

${ }^{63}$ Ricardo GARCíA CÁRCEL, "La psicosis del turco en la España del Siglo de Oro", en Los imperios orientales en el teatro del Siglo de Oro. Ciudad Real, Universidad de Castilla la Mancha, 1994, p. 15.

${ }^{64}$ Francisco FABRO BREMUNDAN, Govierno de los turcos. Maximas, y artes violentas con que se mantiene, y se destruye, $y$ en las quales el P.F. Miguel Fabro de Novi... Madrid: Imprenta de Antonio Roman: 1693, p. 47.

65 "Numa Pompilio dize que instituyo à... al dios Marte doze Salios que truxessen una tunica pintada y ençima del un pectoral de alambre, como le traen nuestros clerigos Christianos...". Guillaume de CHOUL, Discursos de la religión...op.cit. p. 302.

${ }^{66}$ José Miguel MORALES FOLGUERA: "La influencia de la mitografía y de la literatura emblemática en la cultura simbólica de la Nueva España", en Cuadernos de Arte e Iconografía, T.IV, n 8 (1991), pp. 43-44.

67 Jerónimo CORTE REAL, Felicissima Victoria... op.cit.

68 Pierre CIVIL, "Las Relaciones de batallas navales en el Mediterráneo (siglos XVI y XVII): estrategias narrativas"... op.cit. p. 110.

69 Jerónimo CORTE REAL, Felicissima victoria... op. cit.

70 Fernando CHECA CREMADES, "La imagen impresa en el Renacimiento y el Manierismo"... op.cit. p. 60.

71 Marscha SWISLOCKI: "En las fronteras del imperio: Jerónimo Corte Real y la épica luso-castellana... op.cit. p. 1002.

72 Lara VILÀ: "Actium y Lepanto en la épica española del siglo XVI... ", op.cit. p. 76. 